\title{
Pedogenesis in the Barreiras Formation Under Climates of Rio Grande do Norte, Brazil
}

\author{
Lunara G. da S. Rêgo ${ }^{1}$, Jéssia J. A. da Silva ${ }^{2}$, Carolina M. M. Souza ${ }^{3}$, Jeane C. Portela ${ }^{3}$, \\ Isadora N. B. M. de Moura ${ }^{4}$, Ana C. R. da Silva ${ }^{5} \&$ Neyton de O. Miranda ${ }^{3}$ \\ ${ }^{1}$ Graduate Program in Soil and Water Management, Federal Rural University of the Semiarid, Mossoró, Brazil \\ ${ }^{2}$ Agronomist Engineer, Brazil \\ ${ }^{3}$ Center of Agrarian Sciences, Federal Rural University of the Semiarid, Mossoró, Brazil \\ ${ }^{4}$ Graduate Program in Soil Science, Federal University of the Ceará, Fortaleza, Brazil \\ ${ }^{5}$ Graduate Program in Agronomy, Federal University of the Paraíba, Areia, Brazil
}

Correspondence: Lunara G. da S. Rêgo, Programa de Pós Graduação em Manejo de Solo e Água, Universidade Federal Rural do Semi-Árido, R. Francisco Mota, 572-Pres. Costa e Silva, Mossoró, RN, 59625-900, Brazil. Tel: 55-849-9667-1764. E-mail: lunaragleika@hotmial.com

Received: April 30, 2019

doi:10.5539/jas.v11n16p19
Accepted: July 14, 2019 Online Published: September 30, 2019

URL: https://doi.org/10.5539/jas.v11n16p19

\begin{abstract}
In Brazil, the state of Rio Grande do Norte has an important coastal zone and coastal Tableland areas along the Barreiras Formation, but there are few studies to locate and characterize soils with cohesive character. Therefore, this work was carried out to characterize pedons in the western and eastern mesoregions of the state, located in the Barreiras Formation and with different climatic conditions. The profile description and sample collection were carried out in March and April 2016. The characteristics of the profile identified were the sequence of horizons and their depth, soil color, texture, structure, consistency, and transition between horizons. The physical analyzes were of soil density and texture. The chemical analyzes consisted of: $\mathrm{pH}$ in water and in $\mathrm{KCl}$, contents of available $\mathrm{P}$, $\mathrm{Na}^{+}, \mathrm{K}^{+}, \mathrm{Ca}^{2+}, \mathrm{Mg}^{2+}$, potential acidity, and total organic carbon. Indices obtained were: base sum, effective cation exchange capacity, cation exchange capacity at $\mathrm{pH} 7.0$, base saturation, exchangeable aluminum saturation, and exchangeable sodium percentage. The profiles were classified up to the fourth categorical level. The mineralogical assembly was identified in the clay fraction of the diagnostic horizons. The identification of the minerals was performed by X-ray diffraction. The pedons of the two regions presented distinct characteristics and pedogenesis, occurring laterization in the pedons of the western mesoregion and podzolization in the pedons of the eastern mesoregion, both without presence of cohesive character as a diagnostic attribute.
\end{abstract}

Keywords: pedogenesis, climate, podzolization, laterization.

\section{Introduction}

The Barreiras Formation occupies the coastal zone and part of the sub-coastal zone of almost the entire Eastern and Northern Coast of Brazil. The deposition of sediments occurred in the Tertiary period under an arid or semiarid climate and ended during the Pleistocene, with a change to a hot and humid climate (Suguio et al., 1985). The sediments present low levels of $\mathrm{Fe}$ and are essentially kaolinitic, with poorly selected quartz skeleton (Melo, Schaefer, Singh, Novais, \& Fontes, 2002). This favors the compaction of the soils of these origins, with the development of blocky macrostructure, and can give rise to high density soils, with greater amount of micropores and lower permeability, due to the arrangement of the clay fraction (Ferreira, Fernandes, \& Curi, 1999a).

Along the Barreiras Formation, the soils formed in the Coastal Tablelands are the most representative in terms of agricultural land use. These soils have subsurface mineral horizons, which have a friable consistency when wet, but when dry, they present a hard, very hard or extremely hard consistency, exhibiting a strong cohesion (Jacomine, 1996; Ribeiro, 2001a). Its cohesion can be related to the presence of silica and other minerals that can act as cementing agents (oxides and clay), which would cause temporary cementing to break down when the soil is moistened (Ribeiro, 2001b). Another process would be the obstruction of soil micropores by the migration of fine materials to the lower parts of the profile (Giarola \& Silva, 2002), as well as the face-to-face adjustment of the clays, resulting in increased soil density (Ferreira, Fernandes, \& Curi, 1999b). 
The State of Rio Grande do Norte has an important coastal strip and Coastal tracks areas along the Barreiras Group, in this context, the objective of this work was to characterize, through morphological, physical, chemical and mineralogical analyzes, pedons located in the western and eastern mesoregions that compose the Barreiras Group in the State of Rio Grande do Norte and have distinct climatic conditions.

\section{Method}

The study area is located in the municipalities of Mossoró $\left(4^{\circ} 38^{\prime} \mathrm{S}\right.$ and $\left.37^{\circ} 15^{\prime} \mathrm{W}\right)$, in the West region of Rio Grande do Norte (RN), and Baía Formosa $\left(6^{\circ} 22^{\prime} \mathrm{S}\right.$ and $\left.35^{\circ} 00^{\prime} \mathrm{W}\right)$ in the eastern region of the state, which have different climatic characteristics (Figure 1). According to the classification of Köppen (Alvarez, Stape, Sentelhas, Gonçalves, \& Spavorek, 2013), the climate of the West region is of the type BSw'h' (semiarid very hot) and the climate of the Eastern region is As' (tropical rainy with dry summer).

The opening and description of the profiles and subsequent sample collection were carried out in March and April 2016. The first profile (P1) was opened in an area cultivated with melon, belonging to Fazenda Brazil Melon $\left(4^{\circ} 56^{\prime} 13.9^{\prime \prime} \mathrm{S}\right.$ and $\left.37^{\circ} 27^{\prime} 30^{\prime \prime} \mathrm{W}\right)$. The second profile (P2) was opened on the same farm, in an area planted with cashew trees 30 years ago ( $4^{\circ} 56^{\prime} 12.7^{\prime \prime} \mathrm{S}$ and $\left.37^{\circ} 27^{\prime} 22.6^{\prime \prime} \mathrm{W}\right)$, both in the municipality of Mossoró-RN. Profile 3 $\left(6^{\circ} 25^{\prime} 19^{\prime \prime} \mathrm{S}\right.$ and $\left.35^{\circ} 3^{\prime} 3.8^{\prime \prime} \mathrm{W}\right)$ and profile $4\left(6^{\circ} 27^{\prime} 2.6^{\prime \prime} \mathrm{S}\right.$ and $\left.35^{\circ} 3^{\prime} 14.2^{\prime \prime} \mathrm{W}\right)$ were described and collected in an area of native forest at the Casqueira Farm, belonging to Vale Verde Empreendimentos Agrícolas LTDA, in the municipality of Baía Formosa-RN.

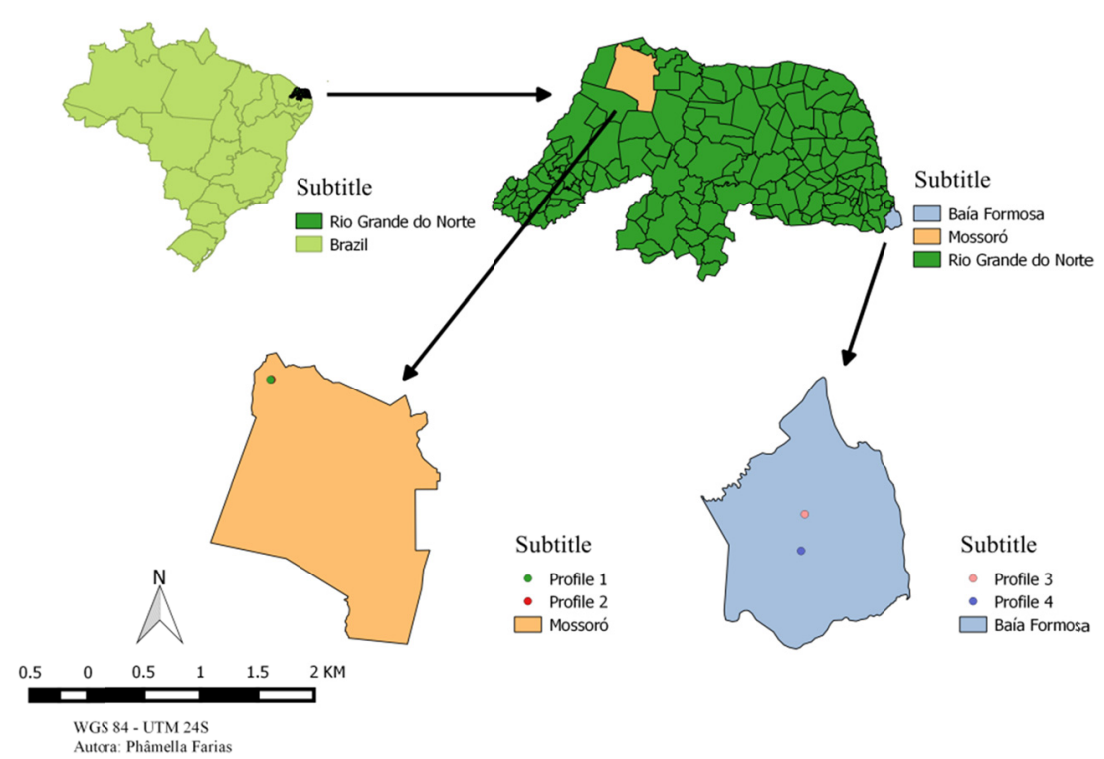

Figure 1. Location of the four soil profiles studied in different climatic condition in regions West and East of the State of Rio Grande do Norte, Brazil

Morphological evaluations of environmental and profile characteristics were performed in each profile. The profile characteristics were the sequence of horizons and their depth, soil color, texture, structure, consistency, and transition between horizons (Santos et al., 2015).

The physical analyzes in triplicates were performed in air dried and sieved soil samples (ADSS) and corrected with the humidity factor (f) for oven dried and sieved soil samples (ODSS). The density was determined by the paraffin sealed clod method using undisturbed samples collected in the field. The texture was determined by the pipette method using the chemical dispersant sodium hexametaphosphate (Teixeira, Donagema, Fontana, \& Teixeira, 2017). After being separated by sieving, the sand fractions were classified according to an adaptation of the range of the Brazilian Society of Soil Science and USDA as very thick sand (2.00-1.00 mm), coarse sand $(1.00-0.50 \mathrm{~mm})$, medium sand $(0.50-0.21 \mathrm{~mm})$, fine sand $(0.21-0.10 \mathrm{~mm})$, and very fine sand $(0.10-0.05 \mathrm{~mm})$.

The chemical analyzes were performed using the samples in the form of ADSS, in triplicate, according to (Teixeira et al., 2017). Soil $\mathrm{pH}$ was determined in water and in $\mathrm{KCl}(1: 2.5)$. The extraction of available $\mathrm{P}, \mathrm{Na}^{+}$ and $\mathrm{K}^{+}$was performed with the Mehlich- 1 solution. The available $\mathrm{P}$ contents were determined by colorimetry and the $\mathrm{Na}^{+}$and $\mathrm{K}^{+}$contents by flame photometry. The extraction of the exchangeable cations $\mathrm{Ca}^{2+}$ and $\mathrm{Mg}^{2+}$ 
was performed with $\mathrm{KCl} 1 \mathrm{~mol} \mathrm{~L}^{-1}$ and the determination of their contents was performed by atomic absorption spectrophotometry. For determination of the potential acidity $(\mathrm{H}+\mathrm{Al})$, the extraction was performed with $1 \mathrm{~mol}$ $\mathrm{L}^{-1}$ calcium acetate at $\mathrm{pH} 7.0$ and the determination was carried out by volumetric titration with a solution of $\mathrm{NaOH} 0.025 \mathrm{~mol} \mathrm{~L}^{-1}$. The total organic carbon (TOC) was determined by the titration with ammoniacal ferrous sulfate of the remaining $0.164 \mathrm{~mol} \mathrm{~L}^{-1}$ potassium dichromate, after the wet oxidation process (Yeomans \& Bremner, 1988). From the analyzes performed, the following indices were obtained: sum of bases (SB); effective cation exchange capacity (t); cation exchange capacity at $\mathrm{pH} 7.0$ (CEC); base saturation (V\%); (m) and exchangeable sodium percentage (ESP), being determined according to Teixeira et al. (2017). The profiles were classified up to the fourth categorical level according to Santos et al. (2018) and correlated with Soil Taxonomy (USDA, 2014).

The mineralogical assembly was identified in the clay fraction of the diagnostic horizons in P1 and P2. The fractions were first separated to obtain only the clay by mechanical and chemical dispersion (Teixeira et al., 2017). In the profiles P 3 and P4 the minerals were identified in the diagnostic horizons, but in the TFSA fraction, due to difficulties in the separation of the granulometric fractions. The identification of the minerals was performed by X-ray diffractometry (XRD), using the XRD-6100 SHIMADZU diffractometer, using k 1 emission of copper. The source potential was $40 \mathrm{kV}$ and the current applied was $30 \mathrm{~mA}$. The sweep speed applied was of a pitch of $0.02^{\circ}$ every second. The scanning range (20) was from 5 to $70^{\circ}$. Peak identification was performed with the aid of the software RaioX v. 1.0.0.37. The minerals were identified according to Chen (1977).

\section{Results and Discussion}

The soil profiles located in the region of the Barreiras Formation presented an intense distinction in relation to its edaphic characteristics, mainly morphological variations, when observed from the West region to the East region of the State of Rio Grande do Norte (Figure 2). Although they are developed from the same lithogenetic formation, which is a set of sedimentary rocks that form the coast of the state of Rio Grande do Norte, there is a significant heterogeneity in relation to the pedogenesis. There is probably an influence of the chemical composition of the sedimentary rocks of these sites, as well as a variation in the fluctuation of the water table associated with the climate, which is totally different between regions. In this way, initially the distinct pedogenesis is attributed to the formation factors, parent material and climate, leading to the formation of soils with distinct features and consequently a divergent agricultural use.
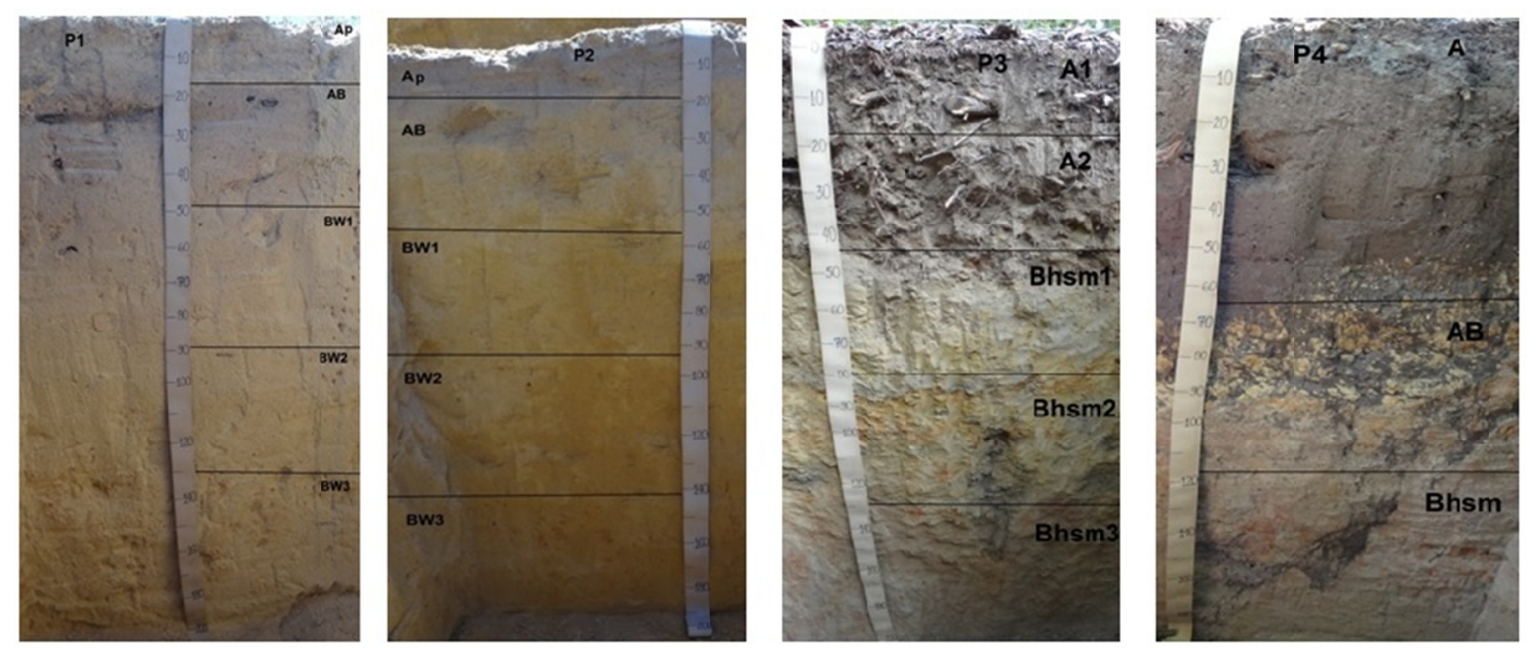

Figure 2. Soil profiles described in regions West and East of the state of Rio Grande do Norte, Brazil. P1 (A) and P2 (B) classified as Latossolo Amarelo Distrófico típico-Lad (Xanthic Haplustox), Ferralsols (WRB/FAO). P3 (C) and P4 (D) classified as Espodossolo Ferri-Humilúvico Hidromórfico dúrico-ESKg (Typic Fragiorthods), Podzols (WRB/FAO)

In the P1 profile a granular structure was verified in almost all the horizons, differing only in the AB horizon, which structures is angular blocks. In all horizons, the soil consistency varied from soft to hard when dry, and from friable to firm when moist, presenting a large amount of micropores. In horizons A and AB, the soil is 
non-plastic and, in the other horizons, the soil presents slight plasticity and stickiness. The horizons in P1 presented predominantly yellowish colors in the matrix, when dry, varying from 2.5 Y $6 / 4$ to 2.5 Y $7 / 4$ (Table 1).

In the $\mathrm{P} 2$ profile, the soil structure is similar to that observed in P1, with the occurrence of many small pores along the profile (Table 1). The consistency is soft in the superficial horizons and slightly hard in the other horizons, keeping the characteristic of very friable in moist soil. In horizons A and AB no plasticity or stickiness was observed, but it was slightly plastic and sticky over the whole Bw horizon. In this profile, all horizons showed yellowish coloration (2.5 Y).

In the Bw3 horizons of profiles P1 and P2 small and distinct mottles were observed, visually very similar to Plinthite, which is formed by a mixture of clay material with quartz grains and other minerals. This formation is low in carbon and rich in $\mathrm{Fe}$, or $\mathrm{Fe}$ and $\mathrm{Al}$, and consolidates irreversibly after several cycles of wetting and drying (Santos et al., 2018). These horizons are yellowish when dry. This facilitates the distinction of this horizon, which is the only one among the three studied that does not have diffuse transition.

The color of the P3 profile was yellowish in the soil background color, while in the mottles there was predominance of colors 10 YR 5/6 and 5 YR 4/6. In P4 there were few changes in color; 10 YR 4/1 to 2.5Y 6/3 There were observed in the background, and 5YR 4/6 to 2.5 YR 4/8 in the mottles. In the moist soil condition, there was no marked difference. The transition from horizons A to Bhsm was abrupt to wavy at P3 and abrupt to irregular at $\mathrm{P} 4$, for the other cemented horizons it was clear to gradual.

Table 1. Morphologic characteristics of described soil profiles from west and east of the State of Rio Grande do Norte, Brazil

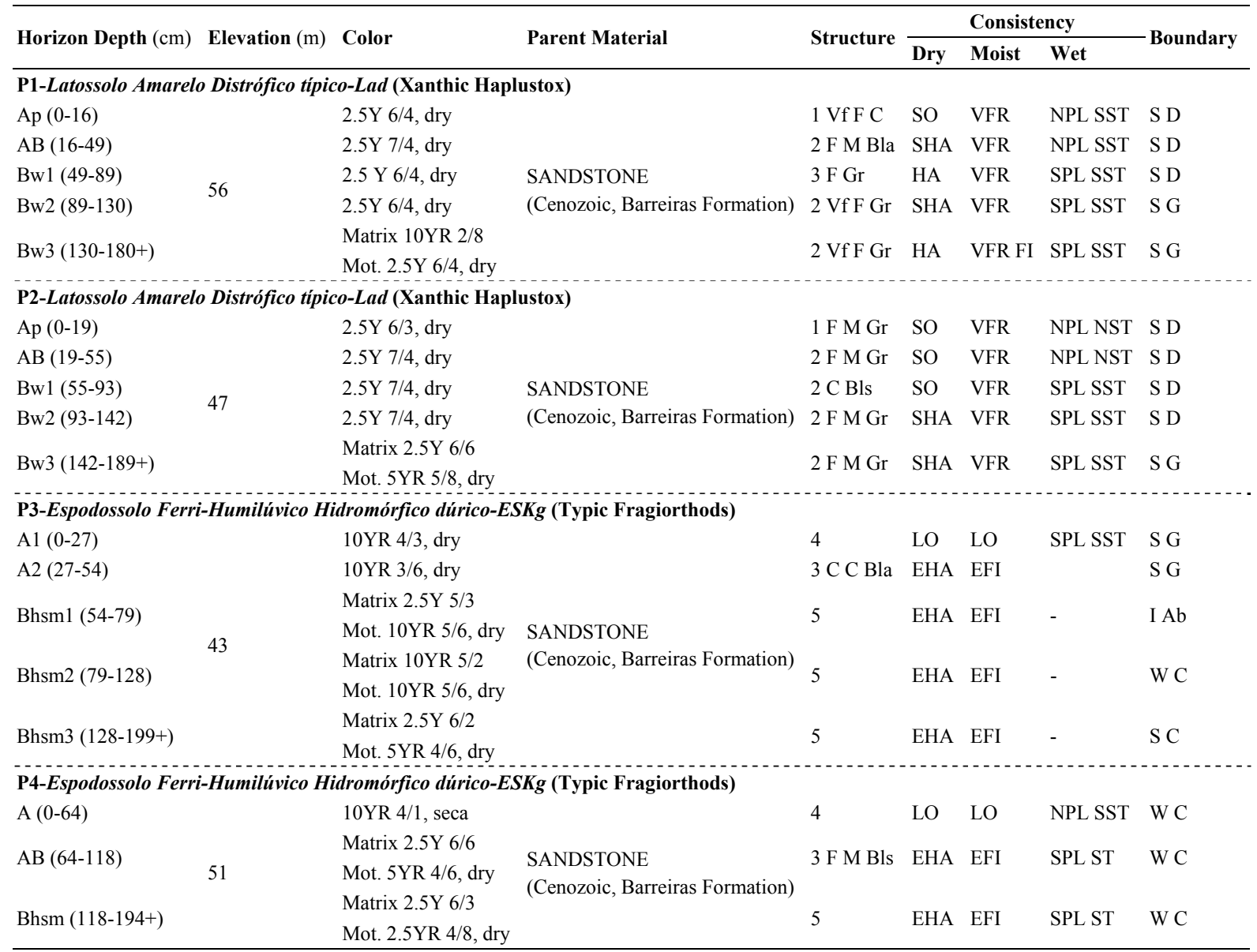

Note. Ele.-elevation. Mot.-mottling. Structure: 1-weak; 2-moderate; 3-strong; 4-single grain; 5-massive; Vf: very fine; F: fine; M: medium; C: coarse; Gr: granular; Bla: angular blocky; Bls: subangular blocky. Consistence: LO: loose; SO: soft; SHA: slightly hard; Ha: hard; EHA: extremely hard; FI: firm; VFR: very friable; EFI: extremely firm. NPL: non plastic; NST: non sticky; ST: sticky; SST: slightly sticky; SPL: slightly plastic. Boundary: S: smooth; W: wavy; I: irregular; D: diffuse; G: gradual; A: abrupt; C: clear. 
No observations were made that denote cohesive character in any of the profiles studied, since this attribute is identified by means of morphological characterization only. According to Santos et al. (2018), the cohesive character is used to distinguish soils with denser subsurface pedogenetic horizons, very hard to extremely hard when dry, becoming friable or firm when moist, being commonly observed between 30 and $70 \mathrm{~cm}$ from the surface. In the morphological characterization of the profiles P1 and P2, it was observed a slightly hard to soft consistency that changed to very friable when wet at depths between 30 and $70 \mathrm{~cm}$. In the case of the profiles $\mathrm{P} 3$ and P4 was observed characteristic of cemented horizon of the Fragipan type. Also, according to Santos et al. (2018), these horizons differ from those that have a cohesive character because they present brittleness (disintegration into smaller fragments).

As for the granulometric composition, the sand fraction predominates in all the evaluated profiles, with higher levels in the superficial horizons, presenting initially a sandy texture (Table 2). The relationship between fine sand and coarse sand shows no divergence which may indicate some heterogeneity of parent material. Therefore, it can be affirmed that the soil formation processes occurred basically on the influence of the landform, or more specifically on the internal drainage of the soil.

Table 2. Physical attributes of described soil profiles from west and east of the State of Rio Grande do Norte, Brazil

\begin{tabular}{|c|c|c|c|c|c|c|c|c|c|}
\hline \multirow{2}{*}{ Horizon and Depth $(\mathrm{cm})$} & \multicolumn{5}{|c|}{ Sand $^{1}\left(\mathrm{~g} \mathrm{~kg}^{-1}\right)$} & \multirow{2}{*}{ Clay } & \multirow{2}{*}{ Silt } & \multirow{2}{*}{ Textural Class } & \multirow{2}{*}{$\mathbf{S D}\left(\mathrm{g} \mathrm{cm}^{-3}\right)$} \\
\hline & $\mathbf{V C}$ & $\mathbf{C}$ & $\mathbf{M}$ & $\mathbf{F}$ & VF & & & & \\
\hline \multicolumn{10}{|c|}{ P1-Latossolo Amarelo Distrófico típico-Lad (Xanthic Haplustox) } \\
\hline Ap $(0-16)$ & 33 & 143 & 415 & 136 & 85 & 159 & 32 & SANDY LOAM & 1.41 \\
\hline AB (16-49) & 17 & 130 & 434 & 160 & 90 & 159 & 10 & SANDY LOAM & 1.51 \\
\hline Bw1 (49-89) & 41 & 151 & 367 & 161 & 92 & 166 & 22 & SANDY LOAM & 1.65 \\
\hline Bw2 (89-130) & 41 & 170 & 286 & 117 & 86 & 242 & 58 & SANDY CLAY LOAM & 1.44 \\
\hline Bw3 (130-180+) & 45 & 147 & 315 & 97 & 73 & 317 & 6 & SANDY CLAY LOAM & 1.35 \\
\hline \multicolumn{10}{|c|}{ P2-Latossolo Amarelo Distrófico típico-Lad (Xanthic Haplustox) } \\
\hline Ap (0-19) & 39 & 212 & 448 & 133 & 66 & 77 & 25 & SAND & 1.69 \\
\hline $\mathrm{AB}(19-55)$ & 23 & 162 & 429 & 171 & 81 & 118 & 16 & LOAMY SAND & 1.65 \\
\hline Bw1 (55-93) & 35 & 153 & 351 & 154 & 85 & 162 & 60 & SANDY LOAM & 1.49 \\
\hline Bw2 (93-142) & 35 & 157 & 288 & 127 & 96 & 244 & 53 & SANDY CLAY LOAM & 1.14 \\
\hline Bw3 (142-189+) & 27 & 136 & 296 & 109 & 89 & 285 & 58 & SANDY CLAY LOAM & 1.51 \\
\hline \multicolumn{10}{|c|}{ P3-Espodossolo Ferri-Humilúvico Hidromórfico dúrico-ESKg (Typic Fragiorthods) } \\
\hline $\mathrm{A} 1(0-27)$ & 35 & 114 & 236 & 352 & 136 & 78 & 48 & LOAMY SAND & 1.30 \\
\hline A2(27-54) & 36 & 116 & 240 & 358 & 138 & 78 & 34 & LOAMY SAND & 1.79 \\
\hline Bhsm1(54-79) & 37 & 114 & 241 & 348 & 134 & 87 & 39 & LOAMY SAND & 1.99 \\
\hline Bhsm2(79-128) & 33 & 112 & 238 & 339 & 139 & 111 & 28 & LOAMY SAND & 1.99 \\
\hline Bhsm3(128-199+) & 37 & 118 & 234 & 324 & 140 & 124 & 23 & LOAMY SAND & 1.68 \\
\hline \multicolumn{10}{|c|}{ P4-Espodossolo Ferri-Humilúvico Hidromórfico dúrico-ESKg (Typic Fragiorthods) } \\
\hline $\mathrm{A}(0-64)$ & 35 & 114 & 236 & 352 & 136 & 116 & 10 & LOAMY SAND & 1.46 \\
\hline $\mathrm{AB}(64-118)$ & 36 & 115 & 239 & 341 & 139 & 121 & 9 & LOAMY SAND & 1.69 \\
\hline Bhsm (118-194+) & 33 & 116 & 236 & 335 & 140 & 132 & 8 & LOAMY SAND & 1.77 \\
\hline
\end{tabular}

Note. VC: very coarse, C: coarse, M: medium, F: fine, VF: very fine. SD: soil density.

Texture is one of the most stable soil characteristics, that is why it is so relevant both for the identification and classification of the soils, and for the prediction of its behavior (Ferreira, 2010). In this aspect, the sand fraction identifies the presence of minerals more resistant to the processes of weathering, and the silt, by its instability, is presented as an indicator of the degree of soil weathering.

In the profiles $\mathrm{P} 1$ and $\mathrm{P} 2$, higher clay content prevailed in the Bw3 horizon, however, the condition necessary to characterize it as a B textural horizon was not observed. Low levels of silt were observed, probably due to the weathering process and consequent mineralogical transformation.

The soil density confirms the morphological results obtained in the field. In the profiles P1 and P2, soil densities between 1.14 and $1.69 \mathrm{~g} \mathrm{~cm}^{-3}$ were observed, and the total porosity was between 32.48 to $57.89 \mathrm{~cm}^{3} 100 \mathrm{~cm}^{-3}$, 
and the subsurface horizons showed a higher porosity (Table 2). In this way it is verified that the soil is perfectly drained, not occurring any restriction to aeration, which favors the flow of rain water or irrigation.

The profiles P1 and P2 were classified as Latossolo Amarelo Distrófico típico-Lad (Xanthic Haplustox), Ferralsols (WRB/FAO), product of the pedogenic process of laterization, reaching approximately $200 \mathrm{~cm}$ depth. They have anthropic horizon A, due to the continuous use of the soil for a long time. They are very developed soils, in which is perceived the intense pedogenetic transformation of the parent material, which, together with a level landform, favors soil drainage.

In profiles 3 and 4 the texture of the horizons was classified predominantly as loamy sand. The clay fraction has values between 78 to $132 \mathrm{~g} \mathrm{~kg}^{-1}$, with higher contents in the subsurface horizons (Table 2). Typic Fragiorthods have materials of origin that are usually very poor in clay, such as quartzites, sandstones or sandy quartzeous sediments, resulting in sandy textured soils along the profile (Carvalho, Ribeiro, Souza Júnior, \& Brilhante, 2013).

The profiles P3 and P4 were classified as Espodossolo Ferri-Humilúvico Hidromórfico dúrico-ESKg (Typic Fragiorthods), Podzols (WRB/FAO), which is the product of the podzolization process. These soils have, as main characteristic, cemented subsurface horizons, massive and with strong presence of mottles, leading to the formation of fragipan type horizons, starting at $60 \mathrm{~cm}$ depth. They have a dark thick A humic horizon with higher soil organic carbon content when compared to P1 and P2 profiles.

According to Souza (1997), the compacted layers may be the result of the predominance of the finer fractions of sand, associated to other factors, such as cementing agents, amorphous organic material and the clay fraction itself. However, the high proportion of fine sand allows a better infiltration of the water and favors the eluviation of the clay to subsurface horizons of the soil (Corrêa et al., 2008). These data contribute to the understanding of the pedogenesis of Typic Fragiorthods, since normally these soil classes have a parent material poor in clay and develop in more sandy sediments.

The density of the soil in the Typic Fragiorthods varied between 1.30 and $1.99 \mathrm{~g} \mathrm{~cm}^{-3}$, showing increase with depth and consequently demonstrating that this behavior is associated to the horizons with massive structure and extremely hard consistency. The B spodic horizon showed a relatively higher density increase, characteristic related to the greater density of the particles in this horizon. It can be observed that the increase of the soil density in depth caused a reduction in the number and size of the pores. Consequently, was observed a reduction of the soil carbon with depth.

The four profiles presented acid reaction, with $\mathrm{pH}$ values ranging from 3.64 to 6.2 (Table 3 ). The values of $\mathrm{pH}$ in $\mathrm{KCl}$ were lower than in water in almost all horizons, mainly in the surface horizons, resulting in negative $\Delta \mathrm{pH}$, which indicates negative net charge, with a predominance of cation exchange in the colloidal fraction. The $\Delta \mathrm{pH}$ presented more negative values in the superficial horizons, a behavior that may be related to the high content of organic matter, mainly in the Typic Fragiorthods, and the occurrence of argillominerals, mainly of the 2: 1 filossilicate group in the subsurface horizons. According to Gomes, Resende, Rezende, \& Mendonça (1998), the surface horizons present, in most cases, higher $\mathrm{pH}$ than the spodic horizons, because they are more leached and practically devoid of organic matter, which is the main source acidity of these soils.

The organic carbon contents were low in profiles P1 and P2. This fact may be related to the semiarid climatic condition to which they are exposed, and it is possible to observe in the horizons Ap the highest amounts of TOC, with approximately $8.7 \mathrm{~g} \mathrm{~kg}^{-1}$. This is due to the influence of the environment, since P1 is located in an area managed with melon for a long period, and P2 in a preserved area with cashew tree occurrence. In the Espodossolos (P3 and P4) the TOC was higher than in P1 and P2, presenting levels between 13.9 and $24.5 \mathrm{~g}$ $\mathrm{kg}^{-1}$. 
Table 3. Chemical attributes of described soil profiles from west and east of the State of Rio Grande do Norte, Brazil

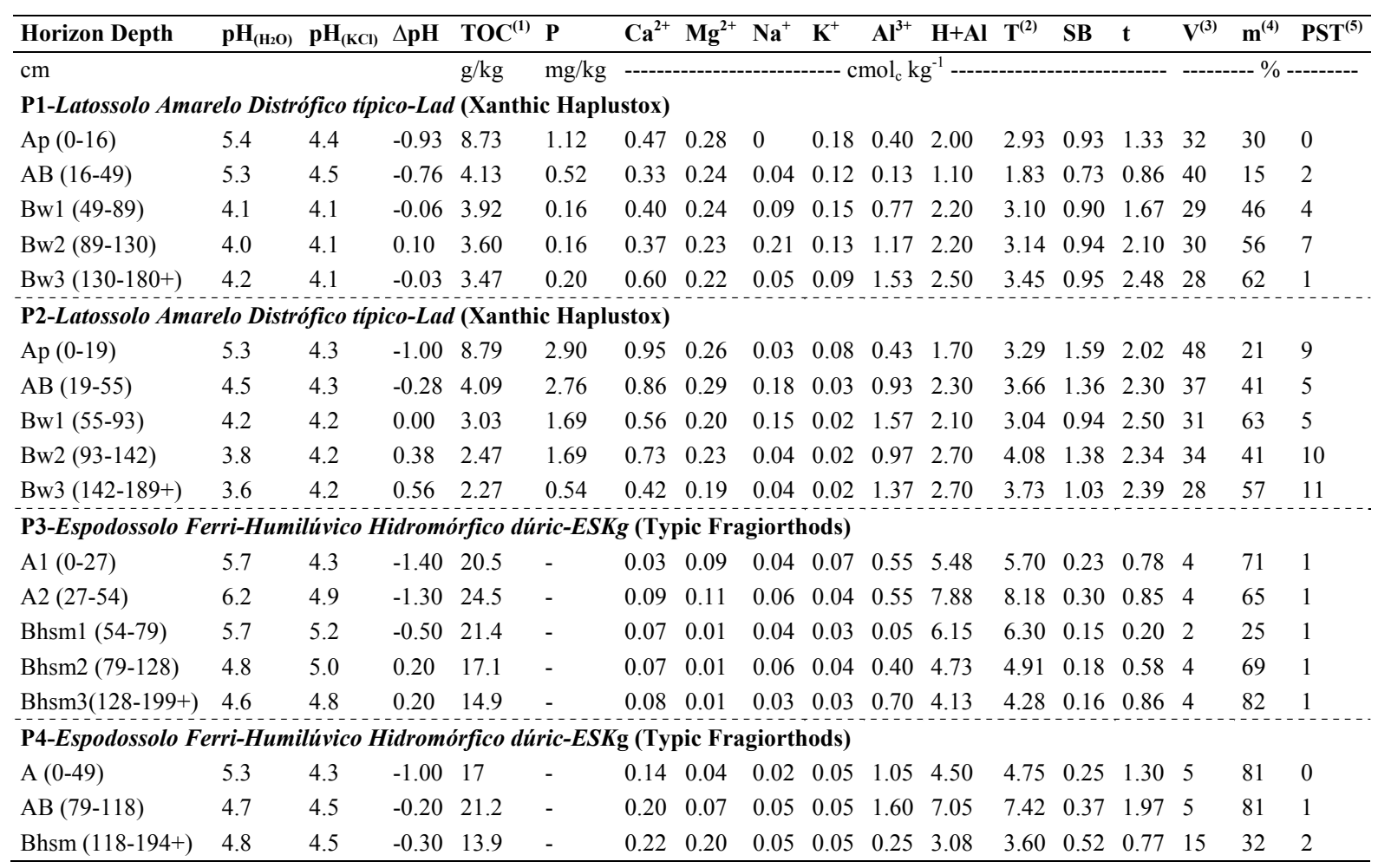

Note. $\mathrm{TOC}=$ total organic carbon; $\mathrm{H}+\mathrm{Al}=$ potential acidity; $\mathrm{T}=$ cation exchange capacity at $\mathrm{pH} 7.0 ; \mathrm{SB}=$ sum of bases. $\mathrm{t}=$ effective cation exchange capacity; $\mathrm{V}=$ base saturation; $\mathrm{m}=$ aluminum saturation; $\mathrm{ESP}=$ exchangeable sodium percentage.

The difference in TOC between regions is related to different rainfall and vegetation. In this sense, the municipality of Mossoró-RN presents an average annual rainfall of $500 \mathrm{~mm}$. The water deficit for prolonged periods favors the decomposition of the vegetal material in surface, not allowing its illuviation to greater depths. In the municipality of Baía Formosa, whose annual precipitation is approximately $1,600 \mathrm{~mm}$, there is a greater availability of water and, consequently, the maintenance of the organic matter input on the soil surface, which allows the addition of carbon to the soil system and its illuviation to deeper layers. The highest levels of TOC in P3 and P4 were always accompanied by high values of potential acidity, whose maximum value was 7.88 cmolc $\mathrm{kg}^{-1}$, while in P1 and P2 it reached 2.70 cmolc kg${ }^{-1}$. A positive correlation of the potential acidity with the organic carbon contents was obtained by Carvalho et al. (2013), in a study of the characterization of Espodossolos in the states of Paraíba and Pernambuco, in northeastern Brazil, probably due to the organic acids present in these soils.

The illuviation of the organic matter to the soil subsurface layers favors a greater loss of bases, having in the complexes of exchange a greater concentration of hydrogen ions, making the soil more acid, and consequently with low saturation by bases. This attribute reached up to $48 \%$ in the profiles P1 and P2, and in P3 and P4 the maximum value of $15 \%$ emphasized the dystrophic character in all horizons $(\mathrm{V}<50 \%)$. According to Kampf and Curi (2009), soils originating from quartz sandstones tend to be poor in bases, with little reserve of nutrients, especially in humid climates, because the good soil permeability favors leaching. According to Carvalho et al. (2013), the low fertility of these soils is reflected by the sum of exchangeable bases, which rarely reach levels greater than $1 \mathrm{cmolc} \mathrm{kg}^{-1}$. That is why these soils are most often characterized as Alic or dystrophic.

The exchangeable aluminum contents were similar in the four profiles, not exceeding $1.60 \mathrm{cmolc} \mathrm{kg}^{-1}$ of soil. In all horizons, potassium contents between 0.02 and $0.18 \mathrm{cmolc} \mathrm{kg}^{-1}$ of soil were observed, and sodium contents between 0.00 and $0.40 \mathrm{cmolc} \mathrm{kg}^{-1}$ were observed. In the profiles $\mathrm{P} 1$ and $\mathrm{P} 2$ the calcium contents varied between 0.33 and $0.95 \mathrm{cmolc} \mathrm{kg}^{-1}$, whereas in P3 and P4, they varied between 0.03 to $0.22 \mathrm{cmolc} \mathrm{kg}^{-1}$. This is attributed to the fact that the basic cations calcium, magnesium, sodium and potassium form more soluble complexes and can be lost more easily by leaching. 
In the Latosols ( $\mathrm{P} 1$ and $\mathrm{P} 2$ ), phosphorus levels varied between 0.16 and $2.90 \mathrm{mg} \mathrm{kg}^{-1}$, being higher in the superficial layers, where the highest TOC concentration occurred. In the Typic Fragiorthods it was not possible to determine the P content through laboratory analysis. These soils, in general, have a sandy texture in the surface horizons, with very low phosphorus retention capacity, so that probably has occurred the transport by illuviation of this element associated with organic matter (Syers \& Walker, 1969). Another possibility is that the phosphorus was in organic form not detected by the extractor used.

The soil profiles studied presented similar mineralogical composition in their respective diagnostic horizons, presenting kaolinite $(\mathrm{Kt})$ as the main product of the pedogenesis. When interpreting the relationship between the parent material and the mineralogical composition of the studied soils, this kaolinite predominance is attributed to the sedimentary deposits that formed the sandstones that compose the Barreiras Fomation, since these rocks are poor in $\mathrm{Fe}$ and rich in $\mathrm{Kt}$, with a with poorly selected quartz skeleton (Melo et al., 2002).

In the profiles P1 and P2 were observed well-defined peaks of Kaolinite, which is a clay-mineral type 1:1, with peaks of different orders (Figure 3), that confirms a high degree of crystallinity of this mineral phase. Also observed is the presence of ilite (I1), which is a 2:1 type clay. This represents a lesser progress in weathering, even if $\mathrm{P} 1$ and $\mathrm{P} 2$ are classified as Oxisols. It is understood that the semi-arid climatic condition contributed to the maintenance of the Illite, which is the only 2:1 clayey type observed along the profile. It is also important to observe the presence of the iron oxide Goethite (Gt), an important soil pigmentation agent that appears in a discrete way, with poorly defined peaks, leading to the interpretation of a lower degree of crystallinity of this mineral phase. The low degree of crystallinity of iron oxides is possibly related to a condition of higher humidity in an earlier period, associated with the fluctuation of the water table. This is confirmed by the presence, in P1 at $\mathrm{P} 2$, of mottles in $\mathrm{Bw} 3$. The presence of iron oxides in a more amorphous condition is difficult to detect by the $\mathrm{X}$-ray diffractometer.

The profiles of Typic Fragiorthods (P3 and P4) presented similar mineralogy, also with well-defined peaks for $\mathrm{Kt}$ and poorly defined for iron oxides, with Gt being the mineral that presented the best condition to identify its interplanar distance (Figure 4). As such samples were evaluated in the form of ADSS, another important mineral was detected, the quartz (Qz), which in general predominates in the mineralogical composition of the sand and silt fraction of the soils. In the study of Typic Fragiorthods in Restinga areas, in the state of Bahia, Oliveira (2007) found kaolinite as the predominant mineral in the clay fraction and, to a lesser extent, quartz and hydroxy-interlayered vermiculite.

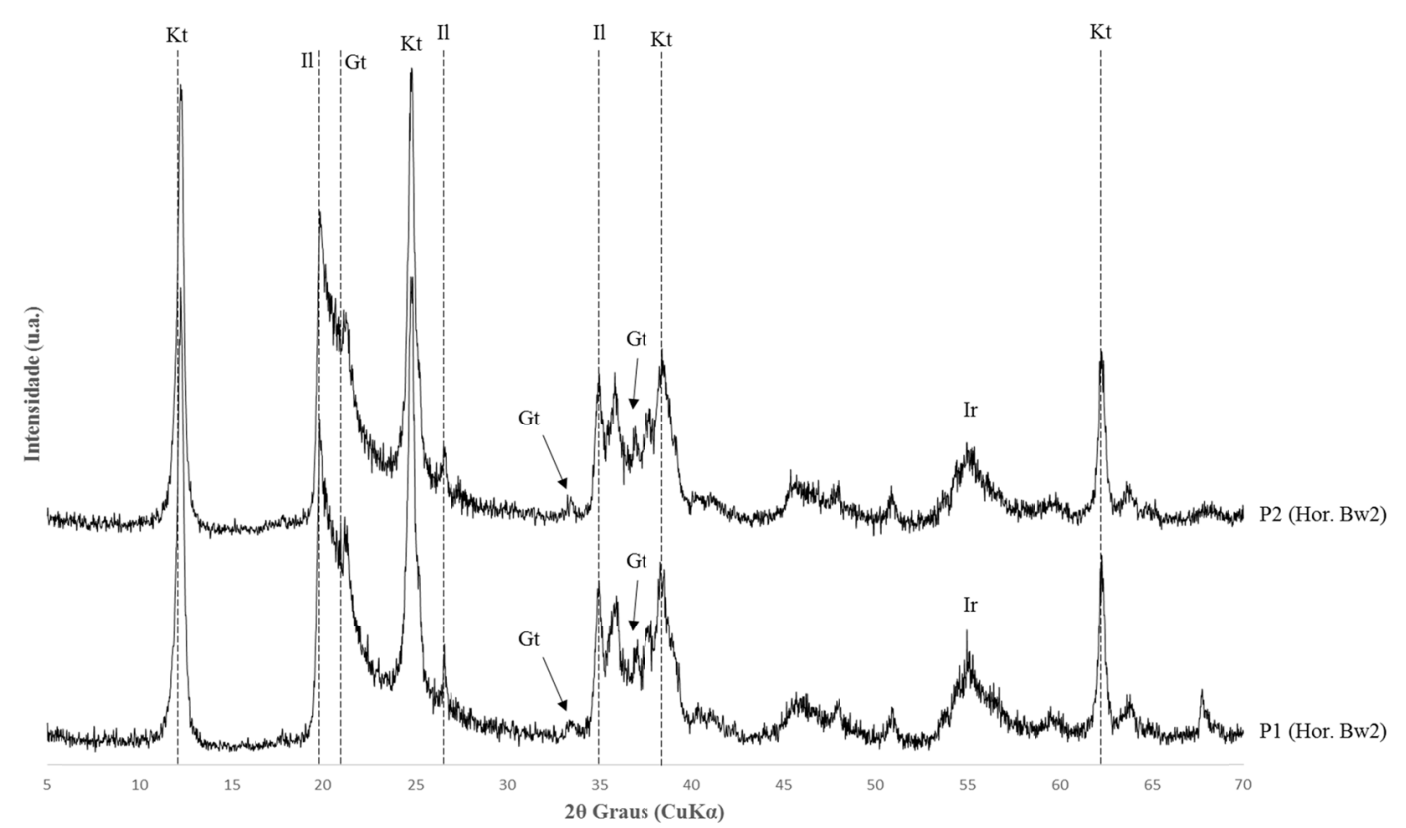

Figure 3. X ray difratometry of clay fraction in the diagnostic horizons in the profiles of Latossolo Amarelo Distrófico típico-Lad (Xanthic Haplustox), Ferralsols (WRB/FAO) (P1) \& (P2).

Kt: kaolinite; Il: Ilite; Gt: Goethite; Ir: iron 


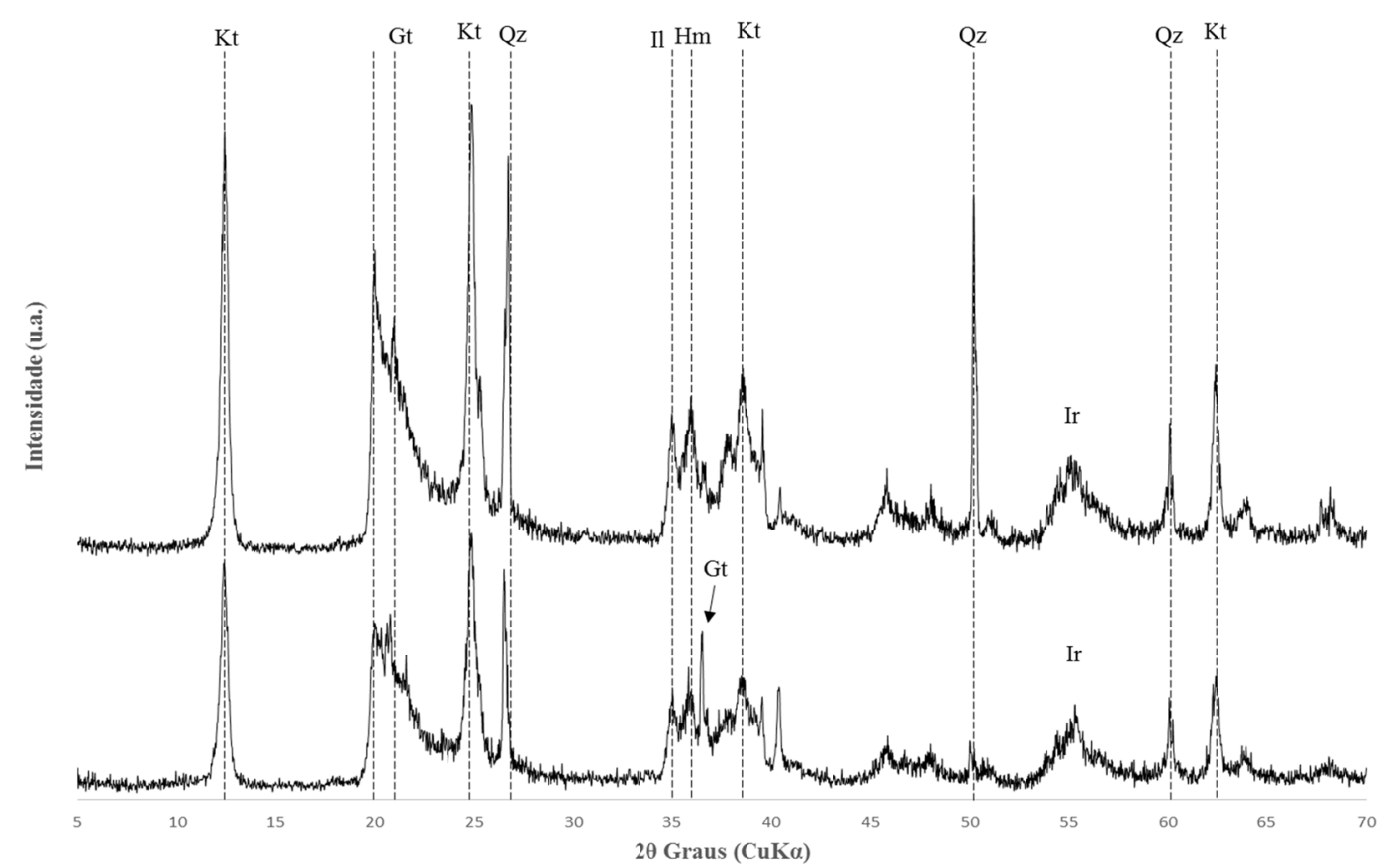

Figura 4. X ray difratometry in the ADSS of diagnostic horizons from profiles of Espodossolo Ferri-Humilivico Hidromórfico dúric-ESKg (Typic Fragiorthods), Podzols (WRB/FAO) (P3) \& (P4).

Ct: Kaolinite; Il: Ilite; Gt: Goethite; Qz: Quartz; Fe: Iron; Hm: Hematite

\section{Conclusion}

The pedons in the Barreiras Fomation, studied in the western and eastern mesoregions of the state of Rio Grande do Norte, Brazil, present distinct pedogenesis and characteristics, and do not present a cohesive character as a diagnostic attribute. The process of laterization occurred in the pedons located in the western mesoregion and the process of podzolization in the pedons of the eastern mesoregion.

In the western mesoregion of Rio Grande do Norte, the pedons studied are classified Latossolo Amarelo Distrófico típico-Lad (Xanthic Haplustox), Ferralsols (WRB/FAO),with anthropic A horizons; vegetation phase Caatinga Hiperxerófila; sandy and kaolinitic; poor in total organic carbon, and with low base saturation.

In the eastern mesoregion, the studied pedons are classified as Espodossolo Ferri-Humilúvico Hidromórfico dúric-ESKg (Typic Fragiorthods), Podzols (WRB/FAO), with humic A horizon; presence of fragipan at $60 \mathrm{~cm}$ of depth; with greater input of organic material; acids; chemically poor; sandy; with strong presence of mottles; being identified in addition to kaolinite, iron oxides and quartz.

Detailed soil knowledge is the basic principle for other related fields, such as geology, geography and environmental sciences. In addition to supporting soil fertility correction, neutralizing the acidity, or knowing about the salinity and/or sodicity of a particular soil type, monitoring soil organic matter, preventing soil erosion among other factors that can be controlled knowing the type of soil and its main strengths and weaknesses.

\section{References}

Alvarez, C. A., Stape, J. L., Sentelhas, P. C., Gonçalves, J. L. M., \& Sparovek, G. (2013). Köppen's climate classification map for Brazil. Meteorologische Zeitschrift, 22(6), 711-728. https://doi.org/10.1127/ 0941-2948/2013/0507

Carvalho, V. S., Ribeiro, M. R., Souza Júnior, V. S., \& Brilhante, S. A. (2013). Caracterização de espodossolos dos Estados da Paraíba e do Pernambuco, Nordeste do Brasil. Revista Brasileira de Ciência do Solo, 37(6) 1454-1463. https://doi.org/10.1590/S0100-06832013000600003

Chen, P. Y. (1977). Table of key lines in X-ray powder diffraction patterns of minerals in clays and associated rocks: Geological Survey Occasional Paper 21. Bloomington: Indiana Geological Survey.

Corrêa, M. M., Andrade, F. V., Mendonça, E. S., Shaefer, C. E. G. R., Pereira, T. T. C., \& Almeida, C. C. (2008). Ácidos orgânicos de baixo peso molecular, ácidos húmicos e alterações em algumas propriedades físicas e químicas de Latossolos, Plintossolo e Neossolo Quartzarênico. Revista Brasileira de Ciência do Solo, 32(1), 


\section{1-131. http://doi.org/10.1590/S0100-06832008000100012}

Ferreira, M. M. (2010). Caracterização Física do Solo. In Q. J. Van Lier (Ed.), Física do Solo. Viçosa, Brazil: Sociedade Brasileira de Ciência do Solo.

Ferreira, M. M., Fernandes, B., \& Curi, N. (1999a). Influência da mineralogia da fração argila nas propriedades físicas de Latossolos da região Sudeste do Brasil. Revista Brasileira de Ciência do Solo, 23(3), 515-524. https://doi.org/10.1590/S0100-06831999000300004

Ferreira, M. M., Fernandes, B., \& Curi, N. (1999b). Mineralogia da fração argila e estrutura de Latossolos da região Sudeste do Brasil. Revista Brasileira de Ciência do Solo, 23(3), 507-514. https://doi.org/10.1590/ S0100-06831999000300003

Giarola, N. F. B., \& Silva, A. P. (2002). Conceitos sobre solos coesos e hardsetting. Scientia Agricola, 59(3), 613-620. https://doi.org/10.1590/S0103-90162002000300030

Gomes, J. B. V., Resende, M., Rezende, S. B., \& Mendonça, E. S. (1998). Solos de três áreas de restinga. II Dinâmica de substâncias húmicas, ferro e alumínio. Pesquisa Agropecuária Brasileira, 33(11), 1907-1919.

Jacomine, P. K. T. (1996). Distribuição geográfica, características e classificação dos solos coesos dos Tabuleiros Costeiros. Proceedings of the 1996 Reunião Técnica Sobre Solos Coesos dos Tabuleiros (pp. 13-24). Cruz das Almas, Brazil: EMBRAPA Tabuleiros Costeiros.

Kampf, N., \& Curi, N. (2009). Formação e Evolução do Solo: Pedogênese. In J. C. Ker, N. Curi, C. E. G. R. Schaefer, \& P. Vidal-Torrado (Eds.), Pedologia: Fundamentos. Viçosa, Brazil: SBCS.

Melo, V. F., Schaefer, C. E. G. R., Singh, B., Novais, R. F., \& Fontes, M. P. F. (2002). Propriedades químicas e cristalográficas da caulinita e dos óxidos de ferro em sedimentos do Grupo Barreiras no município de Aracruz, estado do Espírito Santo. Revista Brasileira de Ciência do Solo, 26(1) 53-64. https://doi.org/ $10.1590 / \mathrm{S} 0100-06832002000100006$

Oliveira, J. B., Jacomine, P. K. T., \& Camargo, M. N. (1992). Classes gerais de solos do Brasil: Guia auxiliar para seu reconhecimento. Jaboticabal: FUNEP.

Oliveira, A. P. (2007). Pedogênese de espodossolos em ambientes da formação barreiras e de restinga do sul da Bahia (Master's thesis, Universidade Federal de Viçosa, Viçosa, Brazil).

Ribeiro, M. R. (2001a). Caractersticas morfológicas dos horizontes coesos dos solos dos Tabuleiros Costeiros. Proceedings of the 2001 Workshop Coesão em Solos dos Tabuleiros Costeiros (pp. 161-168). Aracaju, Brazil: EMBRAPA Tabuleiros Costeiros.

Ribeiro, L. P. (2001b). Evolução da cobertura pedológica dos tabuleiros costeiros e a gênese dos horizontes coesos. Proceedings of the 2001 Workshop Coesão em Solos dos Tabuleiros Costeiros (pp. 93-121). Aracaju, Brazil: EMBRAPA Tabuleiros Costeiros.

Teixeira, P. C., Donagema, G. K., Fontana, A., \& Teixeira, W. G. (2017). Manual de métodos de análise de solo. Rio de Janeiro, Brazil: Embrapa Solos.

Santos, R. D., Lemos, R. C., Santos, H. G., Ker, J. C., Anjos, L. H. C., \& Shimizu, S. H. (2015). Manual de descrição e coleta de solo no campo. Viçosa, Brazil: SBCS.

Santos, H. G., Jacomine, P. K. T., Anjos, L. H. C., Oliveira, V. A., Lumbreras, J. F., Coelho, M. R., ... Oliveira, J. B. (2018). Sistema brasileiro de classificação de solos (5th ed.). Brasília: Embrapa.

Soil Survey Staff. (2014). Keys to Soil Taxonomy (12th ed.). USDA-Natural Resources Conservation Service, Washington, DC.

Souza, L. S. (1997). Aspectos sobre o uso e manejo dos solos coesos dos Tabuleiros Costeiros. Boletim Informativo da Sociedade Brasileira de Ciência do Solo, 22, 34-39.

Suguio, K., Martin, L., Bittencourt, A. C. S. P., Dominguez, J. M. L., Flexor, J. M., \& Azevedo, A. E. G. (1985). Flutuacões do nível relativo do mar durante o Quaternário Superior ao longo do litoral Brasileiro e suas implicações na sedimentação costeira. Revista Brasileira de Geociências, 15(4), 273-286. https://doi.org/ $10.25249 / 0375-7536.1985273286$

Syers, J. K., \& Walker, T. W. (1969). Phosphorus transformations in a chronosequence of soils developed on wind-blown sand in New Zealand. European Journal of Soil Science, 20(1), 57-64. https://doi.org/10.1111/ j.1365-2389.1969.tb01554.x 
Yeomans, J. C., \& Bremner, J. M. (1988). A rapid and precise method for routine determination of organic carbon in soil. Communications in Soil Science and Plant Analysis, 19(13), 1467-1476. https://doi.org/ $10.1080 / 00103628809368027$

\section{Copyrights}

Copyright for this article is retained by the author(s), with first publication rights granted to the journal.

This is an open-access article distributed under the terms and conditions of the Creative Commons Attribution license (http://creativecommons.org/licenses/by/4.0/). 